REVIEW OF HISTORICAL SCIENCES 2018, VOL. XVII, NO. 3

http://dx.doi.org/10.18778/1644-857X.17.03.09

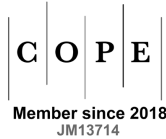

MINOR WORKS AND MATERIALS

Justyna Gazuszka

JAGIELLONIAN UNIVERSITY*

\title{
How did Cracow welcome the Archduchess? Wedding and coronation ceremonies of Anne of Austria and Sigismund III Vasa in 1592
}

$\mathrm{N}$ ational and court ceremonies, which naturally include coronations and weddings of monarchs, have a long history dating back to the Middle Ages. The early modern era considerably developed and improved this tradition, granting it the suitable rank of a cultural as well as political event. It is difficult not to agree with the statement made by Albrycht Stanisław Radziwiłł on the essence of the royal marriage: 'Małżeństwo zwykłych ludzi powstaje ze skłonności dusz, królów zaś dla zadowolenia poddanych' [Marriage of ordinary people arises out of affection of souls, and that of kings for the contentment of the subjects] ${ }^{1}$. Apart from national (and family) functions of these events (funerals, coronations, weddings, births and christenings of children, etc.), these ceremonies were connected by another overriding idea, namely the willingness to show the power of the ruler and stability of his country. Due to mass participation in celebrating different events, members of the society could express their dedication to the dynasty and respect for it, which undoubtedly integrated the given community. Moreover, splendid secular and church

* Faculty of History, Institute of History, Department of Polish Modern History / Wydział Historyczny, Instytut Historii, Zakład Historii Polski Nowożytnej, e-mail: justynagaluszka92@gmail.com.

${ }^{1}$ A.S. Radziwiłł, Pamiętnik o dziejach w Polsce, vol. I (1632-1636), elaborated and transl. A. Przyboś, R. Żelewski, Warszawa 1980, p. 488. 
ceremonial of these festivities gave them an appropriate rank, which was additionally enhanced by cultural and artistic events which accompanied them.

It should, therefore, come as no surprise that these colourful events, which had never reached in the Commonwealth the splendour known from, for instance, the imperial court of the Habsburgs, attracted the attention of contemporaries and aroused common curiosity. Their course also represented an interesting topic to relate in different accounts, correspondence of their participants as well as in occasional literary and historical works. In recent years research into royal wedding ceremonies have brought a lot of new information ${ }^{2}$. It is worth paying attention especially to publications by Anna Filipczak-Kocur, Aleksandra Barwicka-Makula, Karolina Targosz, Mieczysław Rokosz ${ }^{3}$ and Dominik Kadzik ${ }^{4}$ which deal with the topic which is of interest to me in a versatile way. It is also worth mentioning the monumental, four-volume work by Walter Leitsch

${ }^{2}$ The literature concerning coronation and wedding ceremonies is abundant. From the perspective of this article the most important publications include: A. Barwicka-Makula, Stół królewski podczas uroczystości weselnych Zygmunta III Wazy i Anny Austriaczki w 1592 roku, [in:] Historia naturalna jedzenia: miedzy antykiem a XIX wiekiem. Materiały $z$ międzynarodowej konferencji naukowej zorganizowanej przez Muzeum Historyczne Miasta Gdańska i Uniwersytet Gdanski dla upamiętnienia 100-lecia otwarcia Muzeum Wnętrz Mieszczańskich w Domu Uphagena w dniach 3-4 listopada 2011 roku, ed. B. Możejko, Gdańsk 2012, pp. 173-179; A. Falniowska-Gradowska, W. Leitsch, Gonitwa $w$ maszkarach na Rynku Krakowskim (7 czerwca 1592 r.), 'Rocznik Krakowski' 1985, vol. LI, pp. 31-56; A. Filipczak-Kocur, Wesele Zygmunta III i Anny w 1592 r. oraz koronacja królowej $w$ relacjach niemieckojęzycznych $i$ polskich gazet ulotnych, [in:] Wesela, chrzciny $i$ pogrzeby $w$ XVI-XVIII wieku. Kultura życia i smierci, ed. H. Suchojad, Warszawa 2001, pp. 91-104; A. Szweykowska, Widowiska baletowe na dworze Zygmunta III (4 czerwca 1592, 13 oraz 18 grudnia 1605), 'Muzyka' 1966, vol. XI, No. 1 (40), pp. 27-36; K. Targosz, Królewskie uroczystości weselne $w$ Krakowie $i$ na Wawelu w 1512-1605, Kraków 2007; eadem, Oprawa artystyczno-ideowa wjazdów weselnych trzech sióstr Habsburżanek (Kraków 1592 i 1605, Florencja 1608), [in:] Theatrum ceremoniale na dworze ksiąząt i królów polskich. Materiały konferencji naukowej zorganizowanej przez Zamek Królewski na Wawelu $i$ Instytut Historii Uniwersytetu Jagiellońskiego $w$ dniach 23-25 marca 1998, eds M. Markiewicz, R. Skowron, Kraków 1999, pp. 207-244.

${ }^{3}$ M. Rokosz, 'Forum Polonorum et Via Regia'. Rynek krakowski i Droga Królewska scena wydarzeń państwowych, religijnych, narodowych $i$ społecznych 1257-2010, [in:] Rynek krakowski odkryty na nowo, ed. E. Firlet, Kraków 2014, pp. 405-610.

${ }^{4}$ D. Kadzik, Utrzymanie królewskiej teściowej. Wizyta Marii Bawarskiej podczas wesela Zygmunta III Wazy z Anna Habsburg (23 maj- 16 czerwiec 1592 r.), Kraków 2017. 
on the life of king Sigismund III $^{5}$. The aforementioned researchers did not only present the backstage of political preparations for the royal wedding, but they also showed interest in the issues connected with the course of the ceremony or the financial aspect of foreign guests' stay in Cracow. The source grounds of the article are provided primarily by descriptions placed in modern era chronicles written by Marcin Bielski and continued by his son Joachim $^{6}$ who showed these ceremonies, Paweł Piasecki ${ }^{7}$, Reinhold Heidenstein ${ }^{8}$, the chronicle of an anonymous Cracow burgher ${ }^{9}$ and in manuscript accounts ${ }^{10}$. One particularly valuable manuscript is a description of the arrival of the royal couple and gifts given to it during the wedding ceremonies. Its edition may be found in the annex to this $\operatorname{article~}^{11}$. It allows to see the course of the solemn arrival of the Archduchess and her retinue in Cracow, the royal wedding and coronation as well as events held on that occasion, such as feasts, races etc.

The issues raised in this article are important for a number of reasons. Above all, wedding and coronation ceremonies had an important place in the court ceremonial ${ }^{12}$. They were preceded by

${ }^{5}$ W. Leitsch, Das Leben am Hof König Sigismunds III. von Polen, Bd. II, Kraków 2009, pp. 1155-1258.

${ }^{6}$ M. Bielski, Kronika polska, ed. K. Turowski, Warszawa 1829, pp. 1670-1678.

${ }^{7}$ P. Piasecki, Kronika Pawła Piaseckiego biskupa przemyślskiego, transl. J. Bartoszewicz, Kraków 1870, pp. 192-193.

${ }^{8}$ R. Heidenstein, Dzieje Polski od śmierci Zygmunta Augusta do roku 1594: ksiag XII, transl. M. Gliszczyński, elaborated and transl. J. Byliński, W. Kaczorowski, Opole 2015, pp. 602-605. It was modelled on the Königliche Heimfürung magazine in German translated by Ambroży Grabowski: Opisanie wspaniałego wjazdu Anny arcyksiężniczki austriackiej narzeczonej króla Zygmunta III oraz uroczystości jej zaślubienia $i$ koronacyi roku 1592, [in:] A. Grabowski, Ojczyste spominki $w$ pismach do dziejów dawnéj Polski, diaryusze, relacye, pamiętniki i.t.p. służyć mogace do objaśnienia dziejów krajowych tudzież listy historyczne do panowania królów Jana Kazimiérza i Michała Korybuta oraz listy Jana Sobieskiego marszałka $i$ hetmana wielkiego koronnego, vol. I, Kraków 1845, pp. 36-39.

${ }^{9}$ Kronika mieszczanina krakowskiego z lat 1575-1595, ed. H. Barycz, Kraków 1930, pp. 106-132.

${ }^{10}$ Wiazd krolowey polskiey zony Iszey Zygmunta III do Krakowa porzadnie spisany z podarunki, ktore dawano na weselu krola JMSCI 1595! Roku, Biblioteka Kórnicka PAN / The Kórnik Library of the PAS [hereinafter: BK PAN], MS 309; Biblioteka Książąt Czartoryskich w Krakowie / The Princes Czartoryski Library in Cracow [hereinafter: BCz] 197 II, 212 I, 405 I, 456 I, 1977 II [old print]; Biblioteka Jagiellońska w Krakowie / The Jagiellonian Library in Cracow, CIM QU. 5320 [old print].

11 Wiazd krolowey polskiey..., BK PAN, MS 309.

12 B. Fabiani, Na dworze Wazów w Warszawie, Warszawa 1988, p. 102. 
careful preparations and accompanied by cultural events, which is why they remained in the centre of attention of the contemporaries. Accounts of these events were published in numerous ephemeral newspapers e.g. in German, Italian and $\mathrm{Czech}^{13}$ yet there are no reports on them in Polish ephemeral newspapers of the day ${ }^{14}$. Undoubtedly, the intention of the young king was to promote the Polish-Lithuanian Commonwealth and the Vasa dynasty on the international scene, hence the aforementioned reports in foreign languages. The marriage and coronation were not only important events from the viewpoint of the country and dynasty but also due to numerous cultural and artistic events accompanying the wedding which usually lasted several days.

Marriages, especially of monarchs, were predominantly of political character. The House of Vasa, a young dynasty with no established position in Europe, faced the necessity of building prestige through an appropriate matrimonial policy. It is difficult to imagine a better match in the early modern era than the Habsburgs as it was the most influential dynasty of the Old Continent. A marriage with the House of Habsburg added prestige to the Polish-Swedish dynasty. The first wife of Sigismund III, Archduchess Anne, was the daughter of Maria Anna of Bavaria (1551-1608) and Charles II of Austria (1540-1590), a cousin of Holy Roman Emperors Rudolf II and Matthias I, the sister of the future emperor, Ferdinand II (from 1619) and Margaret of Austria, the Queen of Spain (from 1599), wife of Philip III of Spain and Maria Maddalena of Austria, wife of the Grand Duke of Tuscany from $1608^{15}$. The mother of the Archduchess may be described as the architect of her daughter's marriage. She came from the House of Wittelsbach and was the eldest daughter of Albrecht V (1528-1578) and Anna Habsburg (1528-1590). Maria Anna of Bavaria and Charles II of Austria got married in 1571 and had 15 children: six sons and nine daughters. Maria Anna tried to have an impact on the policy in her new country. She was a devout

${ }^{13}$ The catalogue of ephemeral newspapers on the marriage of the Archduchess and the king: K. Zawadzki, Gazety ulotne polskie i Polski dotyczace XVI-XVIII wieku. Bibliografia. Vol. 1, 1514-1661, Wrocław 1977, pp. 59-62.

${ }^{14} \mathrm{~K}$. Zawadzki, Poczatki prasy polskiej. Gazety ulotne $i$ seryjne XVI-XVIII wieku, Warszawa 2002, p. 92.

${ }^{15}$ K. Lepszy, Anna Austriaczka (1573-1598), [in:] Polski słownik biograficzny [hereinafter: PSB], vol. I, Kraków 1935, pp. 132-133; A. Barwicka-Makula, Anna Austriaczka (16 sierpnia 1573 - 10 lutego 1598), [in:] Poczet władczyń Polski, ed. B. Czwojdrak, Kraków 2017, pp. 297-301. 
Catholic supporting Jesuits and she observed the principles of faith. She raised her offspring in that spirit. After her husband's death she did not live in Judenburg, which was given to her as a widow, but instead stayed in Graz ${ }^{16}$.

Even though the future queen, Archduchess Anne, was not particularly beautiful, her certain shortages in appearance were compensated by her family affinities, which made the Archduchess a good match ${ }^{17}$. It was in 1580 under the auspices of the Holy See that first attempts were made to win her hand for the Swedish prince Sigismund Vasa, hence long before the royal election of the son of John III of Sweden and Cathrine Jagiellonian. Initially, obstacles included age, the necessity to convert to Protestantism on the part of Sigismund after succeeding to the throne in Stockholm and, most importantly, the defeat of the House of Habsburg in the rivalry for the crown after the death of Stephen Báthory in 1586. In the Polish-Lithuanian Commonwealth the matrimonial plans of the new king met with discontent of senators who were not in favour of that relationship understood as an element of an ally with the Habsburgs. The issue of the royal marriage was raised many times during the attempts to normalise the relations between the Commonwealth and the Empire which were crowned by the Treaty of Bytom and Będzin of March 9, $1589^{18}$. As it is shown by the research by Kazimierz Lepszy ${ }^{19}$ and the latest study by Aleksandra Barwicka-Makula, the project of the marriage remained in the shade of great politics for several months: recent military conflict over the Polish throne, activities of the Austrian faction in the Commonwealth or finally the unfading claim of the Habsburgs to rule the country on the Vistula River ${ }^{20}$.

${ }^{16}$ More on the life and deeds of Maria Anna of Bavaria in: K. Keller, Erzherzogin Maria von Innerösterreich (1551-1608). Zwischen Habsburg und Wittelsbach, Wien-Köln-Weimar 2012.

${ }^{17}$ On the images of Archduchess Anne e.g. A. Bochnak, Portrety Zygmunta III i Anny Austriaczki w Muzeum Uniwersytetu Jagiellońskiego, 'Prace Komisji Historii Sztuki Polskiej Akademii Umiejętności' [Kraków] 1946, vol. VIII, pp. 327-335; J. Ruszczyc, Portrety Zygmunta III $i$ jego rodziny, 'Rocznik Muzeum Narodowego w Warszawie' [Warszawa] 1969, vol. XIII, part 1, pp. 151-264.

${ }_{18}^{18}$ More on the circumstances of entering into the treaty and the process of its ratification: H. Wisner, Dyplomacja polska $w$ latach 1572-1648, [in:] Historia dyplomacji polskiej, vol. II (1572-1795), ed. Z. Wójcik, Warszawa 1982, pp. 26-29.

${ }^{19}$ K. Le ps zy, Rzeczpospolita Polska $w$ dobie sejmu inkwizycyjnego (1589-1592), Kraków 1939.

${ }^{20}$ A. Barwicka-Makula, Od wrogości do przyjaźni. Habsburgowie austriaccy wobec Polski w latach 1587-1592, doctoral dissertation under the supervision of 
The Senate resolved in 1589 that the future queen should come from a family which is both prominent and Catholic ${ }^{21}$. The senators wished to use the marriage plan with the House of Habsburg to pacify both the contacts with the Emperor and internal relations in the Commonwealth. Sigismund III postponed, however, the final decision about the marriage until his meeting with his father John III of Sweden in Rewal in September 1589. When Maximilian refused to ratify the Treaty of Bytom and Będzin, it seemed that the marriage plans were going to meet with failure as the attitude of the Archduke caused resistance on the part of Polish and Lithuanian senators who previously supported the idea of connecting the House of Habsburg with the Commonwealth ${ }^{22}$. The death of the Archduchess' father, Charles II of Austria, in July 1590 additionally hindered successful resolution of this issue.

Negotiations concerning the marriage were resumed at the turn of 1590 and 1591 on the initiative of Emperor Rudolf II, who ordered his envoys, the Bishop of Wrocław Andreas Jerinow (1540-1596) and Richard Strein (1538-1600), to hold talks with the young Vasa ${ }^{23}$. It was then that the papal diplomacy joint in the endeavours to the hand of the Archduchess: both the Court Crown Marshal Andrzej Opaliński and the apostolic nuncio Hannibal of Capua were asked to get deeply involved in the issue of the marriage of Sigismund III with the religious and pious woman ${ }^{24}$. The potential betrothed couple exchanged their portraits and letters. The opposition in the PolishLithuanian country, led by the Chancellor Zamoyski and the Field Hetman of the Crown Stanisław Żółkiewski, threatened not to allow the Archduchess to enter the Commonwealth. The backstage of the dispute between the monarch and noblemen is revealed in a letter of the Hetman and the Grand Chancellor of the Crown Jan Zamoyski ${ }^{25}$ which is full of bitterness and reproaches. Despite these adversities

Associate Professor R. Skowron PhD, Katowice 2013, https://fbc.pionier.net.pl/ details/nn8gSZ1 (online: December 18, 2017).

${ }^{21}$ K. Lepszy, op. cit., p. 43.

${ }^{22}$ Ibidem, p. 95.

${ }^{23}$ A. Barwicka-Makula, Od wrogości..., p. 342.

${ }^{24}$ Clement VIII to Opaliński, Rome, January 20, 1591, BK PAN, MS 245, sheet 241; Clement VIII to Hannibal of Capua, Rome [no date], ibidem, sheets 241-241v. Incidentally, the Pope was still George XIV (1535-1591), who died on October 16, in Rome. His successor was Clemens VIII (1536-1605), Pope from January 30, 1592.

${ }^{25}$ Jan Zamoyski to Sigismund III, Zamość, January 27, 1591, BCz, MS 351, pp. 17-19. 
the king made the decision about marrying the Archduchess. In her letter to her future son-in-law Maria of Bavaria, the mother of the Archduchess, expressed her joy, informing at the same time about her plans to go to the Commonwealth ${ }^{26}$. Entering into marriage by the monarch was preceded by diplomatic talks as well as negotiating the conditions of the wedding contract and the dowry.

In spring the following year a legation was sent to Rudolf II which consisted of the Bishop of Kujawy Hieronim Rozrażewski (about 1546-1600) ${ }^{27}$ and the Grand Chancellor of Lithuania Albrycht Radziwiłł (1558-1592) ${ }^{28}$. In Vienna they were joint by the Cardinal Jerzy Radziwiłł (1556-1610), who acted as a representative of the Pope $^{29}$. The marriage agreement was executed in Prague on April 17, 1592, and the envoys headed for Vienna, where the royal fiancée was expecting them with her mother Maria and fraternal cousins, Archdukes Ernest and Matthias (later the Holy Roman Emperor Matthias I of Habsburg) ${ }^{30}$. The proxy marriage in Vienna (May 3, 1592), which was performed by the Cardinal Radziwiłl, and Sigismund III was represented by the Grand Marshal, was followed by a feast and dancing. It was attended by the mother of the Archduchess, Maria of Bavaria, as well as Ernest and Matthias ${ }^{31}$. Franciszek Siarczyński cites an interesting custom which accompanied proxy marriages, namely the marriage should be completed by the so-called bedding ceremony: 'jeden $z$ posłów polskich pierwszej po ślubie nocy, cały w zbroję odziany obok królowej się położył, podług obrządku (...) jaki królowie polskich w takowym przypadku zachowywać zwykli' [on the first night after the wedding, one of the Polish envoys, all clad in armour, lay down beside the queen according to the rite (...) which the Polish kings used to observe in such a case $]^{32}$.

${ }^{26}$ Maria of Bavaria to Sigismund III, Graz, 1592, BK PAN, MS 245, sheets $245 \mathrm{v}-246$.

${ }^{27}$ A. Barwicka, Hieronim Rozdrażewski (Rozrażewski) (ok. 1546-1600), [in:] Polscy dyplomaci w Wiedniu 1515-2015, ed. B. Dybaś, Wiedeń 2015, pp. 44-45.

${ }^{28}$ A. Kalinowska, Albrycht Radziwiłt (1558-1592), [in:] ibidem, pp. 52-53.

${ }^{29}$ King Sigismund III to Emperor Rudolf II, Kraków, August 19, 1591, [in:] The house of Vasa and the house of Austria: correspondence from the years 1587 to 1668. Pt. 1, The times of Sigismund III, 1587-1632. Vol. 1, ed. R. Skowron, Katowice 2016, pp. 256-258.

30 Ibidem.

${ }^{31}$ The 'Austrian' part of wedding ceremonies was presented in: K. Vocelka, Habsburgische Hochzeiten 1550-1600. Kulturgeschichtliche Studien zum manieristischen Repräsentationsfest, Wien 1976, pp. 120-124.

${ }^{32}$ F. Siarczyński, op. cit., pp. 380-381. 
After the wedding Anna set off with her retinue of 431 people $^{33}$ to her new country. She was accompanied by her mother, imperial envoys Georg IV Ludwig Landgraf von Leuchtenberg and the Bishop of Wrocław Andreas Jerin, albeit he joined the retinue in Pszczyna, as well as envoys of Sigismund III. Like in the case of previous journeys they headed for Cracow. They crossed the borders of the Commonwealth on May 14. The Archduchess was first met by senators with their retinues, welcomed on behalf of her spouse in Balice and escorted to Łobzów, where Sigismund III was awaiting her. Among people welcoming the future queen was Wawrzyniec Goślicki, the bishop of Przemyśl. In the light of the description by the Cracow burgher the retinues of both the Archduchess and the monarch were really splendid and they both looked lavish. Also the representatives of lower classes, namely the burghers and commons of Cracow, Kazimierz and Kleparz, came to greet the future queen. The king stayed in Łobzów, where four decorative tents were put up, which were designed the Turkish fashion and were really sumptuous, according to the description of the author of the chronicle. Sigismund III was accompanied by 'the old queen' Anna Jagiellon and his sister, the Princess Anna Vasa of Sweden. The Archduchess was welcome on behalf of the king by Jan Tarnowski, and Andreas Jerin replied to him. After the greeting they all entered Cracow in a set order: first the city cavalry, the royal cavalry, horse retinues, then Sigismund III on horseback surrounded by imperial envoys, after them Archduchess Anne with her mother in a coach. They were followed by Queen Anna Jagiellon and princess Anna, wives of dignitaries, the future queen's and Polish ladies-in-waiting. The whole procession comprised 4900 cavalry, 5700 dismounted and 262 people in coaches. It was even possible to see in the procession two camels which were led by Turks. Different languages were heard: ‘jedni po włosku, drudzy po murzyńsku, drudzy po arabsku, drudzy po turecku'34 [some spoke in Italian, others in African, others in Arabic, others in Turkish], as it was described by the Cracow burgher. He also commented on the appearance of Poles who went to great lengths to look dignified during this ceremony.

It was in 1592 that triumphal gates were erected for the first time to welcome the new queen. Five constructions of this type were built

${ }^{33}$ K. Vocelka, op. cit., p. 120.

${ }^{34}$ Kronika..., p. 107. 
on the route of the procession: in the vicinity of St Florian Church, behind St Florian's Gate, at the crossing of Florianska Street and the Market, on Grodzka Street and the last one right in front of the Wawel Castle ${ }^{35}$. One may even argue that the erection of triumphal gates alluded to the antique custom of crowning military successes with such constructions ${ }^{36}$. The greatest sensation, however, was caused by a subject of Stanisław Stadnicki who climbed the top of the St Mary's Tower with a white and red flag with a huge white eagle painted on $\mathrm{it}^{37}$. The wedding and coronation of the new queen as well expected political benefits connected with it were perceived as one of the successes of the monarch, even though the political situation in the country was unfavourable at that time ${ }^{38}$. The artistic side of the event was also outstanding: the procession was accompanied by musicians, songs were sung, both the castle and tenement houses on the route of the procession were redecorated ${ }^{39}$. Both Pawel Piasecki and the aforementioned Cracow burgher stress that the most expensive fabrics were bought to decorate tenement houses and during the night they were lit by lanterns with candles. The solemn arrival lasted from $3.00 \mathrm{pm}$ to $6.30 \mathrm{pm}^{40}$. Having arrived at the Wawel Hill the procession headed for the cathedral where the Archduchess was greeted by the Cracow Chapter and Te Deum laudamus was solemnly sung. The king accompanied Anne with her mother to the rooms in the Hen's Foot Tower. Cannons were fired, both in the Castle and in the city.

The subsequent part of celebrations took place on Sunday May 31, 1592 (preceded by a Corpus Christi procession watched by the mother of the Archduchess from the Castle $)^{41}$. The Polish and Lithuanian nobility came to the confirmation of wedding and coronation of Anna. Servants and onlookers had to stay outside the Castle. Also the wedding retinue was adequately formed: the king was dressed in

${ }^{35}$ Ibidem, p. 112; M. Rożek, Uroczystości w barokowym Krakowie, Kraków 1976, pp. 33-34.

${ }^{36}$ J.A. Chrościcki, Barokowa architektura okazjonalna, [in:] Wiek XVII. Kontrreformacja. Barok, ed. J. Pelc, Wrocław 1970, p. 232.

${ }^{37}$ M. Rożek, Polskie koronacje i korony, Kraków 1987, p. 64.

${ }^{38} \mathrm{~K}$. Targosz, Oprawa artystyczno-ideowa wjazdów weselnych trzech sióstr Habsburżanek (Kraków 1592 i 1605, Florencja 1608), [in:] Theatrum ceremoniale..., p. 213.

${ }^{39}$ A. Leszczyńska, O muzyce $w$ obrzędach koronacyjnych królów polskich, 'Polski Rocznik Muzykologiczny' 2015, vol. XIII, pp. 85-86.

${ }^{40}$ Kronika..., pp. 111-113.

${ }^{41}$ Ibidem, p. 114. 
a cape and alb, he had a crown on his head and the remaining royal insignia in his hands: the globus cruciger and sceptre. Sigismund III walked in the company of the Bishop of Cracow Jerzy Radziwiłl and the Bishop of Płock Wojciech Baranowski. They were followed by the Archduchess in the company of the Archbishop of Lviv Jan Dymitr Solikowski and the Bishop of Łuck Bernard Maciejowski. The crown, globus cruciger and sceptre were carried in front of the future queen ${ }^{42}$. Then came Anna Vasa together with Archduchess Maria, who were led by imperial envoys. In that order the procession headed for the Cracow Cathedral where a solemn holy mass was celebrated. The rite of marriage was performed by Cardinal Jerzy Radziwiłl followed by the coronation of the Archduchess. The crowner was the Bishop of Kujawy Hieronim Rozrażewski representing the Primate Stanisław Karnkowski who excused himself with a supposed illness, which was strongly opposed by Solikowski ${ }^{43}$. Although the account of these events may suggest that confirmation of marriage and the wedding were one, in reality these were two separate acts ${ }^{44}$.

After these festivities the procession went to the Castle. Sigismund III changed his coronation vestment, while the new queen stayed in her attire and participated in the wedding feast which lasted till $10 \mathrm{pm}$ with a crown on her head ${ }^{45}$. The solemn dinner was described in the sources in a relatively accurate manner: the products which the dishes were made of were described as well as the interior decorations or number of participants, stressing the absence of ill Anna Jagiellon ${ }^{46}$. The wedding festivities lasted till June 7 . They included feasts, dancing as well as costume and ballet performances, theatre performances or knight races in which the king himself took part ${ }^{47}$. According to Stanisław Windakiewicz, the intention of the monarch was to outshine the wedding celebrations of Griselda Báthory and Jan Zamoyski of June $12,1583^{48}$.

${ }^{42}$ S. Windakiewicz, Dzieje Wawelu, Kraków 1925, p. 116.

${ }^{43}$ R. Heidenstein, op. cit., p. 604. As it is argued by A. Barwicka-Makula, the illness of Karnkowski was a diplomatic way of justifying his absence during the coronation. See eadem, Od wrogości..., p. 356.

${ }^{44}$ S. Kutrzeba, Koronacje królów i królowych w Polsce, Warszawa 1918, pp. 20-22.

${ }^{45}$ Kronika..., p. 119.

${ }^{46}$ A. Barwicka-Makula, Stół królewski..., pp. 177-178.

${ }^{47}$ A. Falniowska-Gradowska, W. Leitsch, op. cit., pp. 31-56.

${ }^{48}$ S. Windakiewicz, op. cit., p. 117. On the wedding of J. Zamoyski e.g. E. Dubas-Urwanowicz, Wesele Jana Zamoyskiego z Gryzelda Batorówną, 'Białostockie Teki Historyczne' 2011, vol. IX, pp. 237-251. 
Also literary works were composed on the occasion of the wedding, including Epithalamium na wesele Zygmunta III $i$ arcyksiężniczki J.M. rakuskiej Anny written by Andrzej Zbylitowski and the work by Szymon Szymonowic also entitled Epithalamium. Their careful perusal may reveal that Szymonowic was much more careful in his compliments than Zbylitowski, who widely praised the beauty and virtues of theyoungqueen. Szymonowic most ofall begged Anna tolisten attentively to the voices of citizens of the Commonwealth murdered by the Tatars on Podolia ${ }^{49}$. Joachim Bielski ${ }^{50}$ and Stanisław Sokołowski should be also mentioned among authors of commemorative works composed after the wedding of the Archduchess and the Polish king $^{51}$. The remaining works were collected by Karol Estreicher in his Bibliografia ${ }^{52}$.

The accounts devoted to the wedding ceremony of Anne and Sigismund as well as the coronation of the new queen allow to reconstruct the course of these events in a meticulous way. The act of coronation alone may be compared to similar ceremonies of Polish kings while another issue is the artistic side of royal arrivals and wedding. It is possible to explore it due to numerous descriptions which allow to reconstruct this special occasional architecture, by definition doomed to liquidation ${ }^{53}$. Elaborate fabrics, coats of arms, monograms, pictures, lighting elements, elements made of wood, plaster, paper pulp or canvas, finally triumphal gates: all these composed a complex and elaborate composition which added splendour to the moment of welcoming the queen in her new country.

The celebrations which are subject to analysis in this article are unique also for other reasons. Above all, these were penultimate welcoming and wedding festivities which took place in Cracow from the beginning to the end (the last ones took place in 1605 on the

${ }^{49}$ E. Rudzki, Polskie królowe. Żony królów elekcyjnych II, Warszawa 1987, p. 53. More on the subject: J. Nowak-Dłużewski, Okolicznościowa poezja polityczna w Polsce. Zygmunt III, Warszawa 1971, pp. 334-336.

${ }^{50}$ Reprints in: Ioachimi Bilscii Carmina Latina. Nuncprimum in unum volumen collecta, ed. T. Bieńkowski, Warszawa 1962, pp. 113-116; and M. Malicki, Joachima Bielskiego nieznane polskie 'Epithalamion' na ślub Zygmunta III i Anny Austriaczki, 'Biuletyn Biblioteki Jagiellońskiej' [Kraków] 1994, vol. XLIV, No. 1-2, pp. 119-129.

${ }^{51}$ L. Grzebień, Sokołowski (Socolovius) Stanisław h. Gozdawa (1537-1593), [in:] PSB, vol. XL, Warszawa-Kraków 2000-2001, pp. 183-189.

${ }^{52}$ K. Estreicher, Bibliografia polska, vol. XII, Kraków 1891, pp. 162-163.

${ }^{53} \mathrm{~K}$. Targosz, Królewskie uroczystości weselne $w$ Krakowie $i$ na Wawelu w 1512-1605, Kraków 2007, p. 16. 
wedding of Archduchess Constance and Sigismund III). Cracow celebrations in 1592 were long: they lasted about two weeks, some elements of the programme (feasts, balls, ballet, theatre performances, tournaments and masquerades) were interwoven with church and country ceremonies. They were closing, in a way, the epoch of Renaissance in the Commonwealth ${ }^{54}$. It was not until about a fortnight later that the guests endowed by the king parted and life on the royal court came back to normal. These events, due to accounts in German, Italian or $\mathrm{Czech}^{55}$, were disseminated among Western recipients. Inhabitants of European countries got to know about several-day cultural and artistic programme, showing the splendour of the Polish-Lithuanian court. They played an important role in shaping the public opinion in Europe on the young monarch of the Commonwealth, his surroundings and friendship with the Habsburgs whose symbol was the marriage concluded in 1592 . It is also admirable to see the splendour with which these events were organised, taking into account the difficult both internal and external situation of the country and uneasy beginnings of the rule of the first monarch from the Vasa dynasty (divided election, necessity to compete with a representative of the most important ruling family on the European continent, internal opposition etc.).

The arrival of the first wife of Sigismund III may be analysed also iconographically as two artistic representations of these events were preserved. The solemn welcome of Archduchess Anna was depicted on an engraving attached to the German account Königliche Heimführung ${ }^{56}$. It exposes the moment of the meeting of the royal couple and arrival of the main figures to city walls. It shows numerous armed detachments and gathered people ${ }^{57}$. The second representation, stored in the Princes Czartoryski Library in Cracow, also presents the arrival of the Archduchess Anne in $\mathrm{Cracow}^{58}$. Also a commemorative medal was made with the busts of Sigismund III and his newlywed spouse ${ }^{59}$. It is necessary to discuss separately the rite of coronation which did not differ from the rite established during the reign of Sigismund I the

${ }^{54}$ Ibidem, p. 5.

${ }^{55}$ K. Zawadzki, Gazety ulotne..., pp. 232-241.

56 The Historical Museum of the City of Cracow, ref. code MHK-909/VIII.

${ }^{57} \mathrm{~J}$. Pirożyński, Krakowskie uroczystości państwowe $i$ dworskie $w$ drugiej połowie XVI wieku $w$ świetle ówczesnych prototypów prasowych, [in:] Theatrum ceremoniale..., p. 197.

${ }^{58} \mathrm{BCz} 405 \mathrm{I}$.

59 The National Museum in Cracow, ref. code MNK VII-Md-186. 
Old used in the ceremonies in 1512 and 1518 with Barbara Zápolya (died 1515) and Bona Sforza (1494-1557) respectively, enriched with numerous accompanying events: theatre performances, feasts etc. The rite of coronation took place during the holy mass. When the Litany of the Saints was being sung, the new queen was prostrating, then her right hand and her back between scapulae were anointed. After that the bishop crowner took off the wreath from her head and put a crown on it, and the queen was given a globus cruciger and a sceptre into her hands and she was walked to the throne which was prepared for her next to her spouse ${ }^{60}$.

Marrying into the House of Habsburg appeared to be fortunate for Sigismund III, which is not a rule in the case of royal marriages. The monarch loved his wife, they got on well, and she gave him offspring that prolonged the rule of the Vasa dynasty in the Commonwealth. It is also worth highlighting the wedding festivities which took place in Cracow. They were modelled on similar events held on Western European courts and they met their standards. In particular the wedding and coronation of Anne of Austria became not only a political event but also a cultural and social one.

The source edition was prepared in accordance with the publishing instruction for historical sources by Kazimierz Lepszy ${ }^{61}$. Taking into consideration, however, that these principles do not fully correspond to the contemporary requirements of critical editing, I tried to introduce changes which would preserve, on the one hand, the style and purport of archaic Polish and, on the other, become clear and understandable for all readers, including non-specialists in the field of either history or the Polish language. I decided to replace title abbreviations in the form of capital clusters with full names: 'Wmć' = 'Waszmość' [Sir], 'JP' = 'Jaśnie Pan' [His Lordship] as well as other abbreviations in the text. I adopted the principle of full translation of Latin expressions written in italics in the edition, in square brackets '[]', which is currently a standard requirement in editing old Polish texts. If it was impossible to read a fragment of the text, I marked this fact by '[...]'. I updated the punctuation and corrected language mistakes, which gave some words their contemporary shape e.g. 'prędko' in the place of 'prettko' [quickly]. I decided, however, to preserve the original shape of both proper and geographical names, hence the reader

${ }^{60}$ M. Rożek, Polskie..., pp. 57-58.

${ }^{61} \mathrm{~K}$. Lepszy, Instrukcja wydawnicza dla źródeł historycznych od XVI w. do poł. XIX w., Warszawa 1953. 
will find such expressions in the text as: 'Hanszpach' [Margrave of Ansbach] etc. This also refers to the beauty and specific flavour of sixteenth-century Polish, hence I preserved words in accordance with their previous pronunciation: 'okazyją' [occasion] 'będziem' [we shall], 'wjachaniu' [entering], 'wszystkę' [all], 'naszemi' [our], 'Polszcze' [Poland], 'powiedamy' [we say], 'przyjachał' [he arrived] etc.

\section{Source text}

Or.: Biblioteka Kórnicka PAN / The Kórnik Library of the PAS, MS 309, sheets $1-9$.

[sheet 1]

${ }^{a}$ Wjazd Królowej Polskiej żony 1-szej Zygmunta III do Krakowa porządnie spisany $z$ podarunki, które dawano na weselu Króla Jmci 1595 roku $^{62}$.

Anno 1595

\section{A naprzód}

Po wjechaniu Jego Mości do Krakowa die [dnia] 22. Aprilis [kwietnia]. Wiedząc Król Jegomość o przyjeździe Arcyksiężny Jej Mości, wysłał $\mathrm{k}<$ siędza $>$ Baranowskiego biskupa płockiego ${ }^{63}$ i Pana Malagowskiego $^{64}$ die [dnia] 11. Maii [maja], która oni potkali za Freysztatem ${ }^{65}$ mila.

Dnia 15. Mai [maja] potem Jego Mość Pan marszałek litewski ${ }^{66}$, zostawiwszy biskupa kujawskiego ${ }^{67}$ przy niej na granicy [sheet $1 \mathrm{v}$ ], sam naprzód do Krakowa przyjachał, częścią oznajmując Król Jego Mość o przybyciu Królowej Jej Mości, częścią dla złego zdrowia

${ }^{62}$ An evident mistake of the writer: the wedding of Anna of Austria and Sigismund III Vasa took place in 1592.

${ }^{63}$ Wojciech Baranowski (1548-1615) - the bishop of Płock from 1591 to 1608.

${ }^{64}$ This is probably about Sebastian Lubomirski (ca. 1546-1613), the castellan of Małogoszcz.

${ }^{65}$ Fryštát - town in the previous Duchy of Teschen belonging to the Kingdom of Bohemia. In the second part of the $16^{\text {th }}$ century the so-called Fryštát State Country was formed, consisting of the town and several villages.

${ }^{66}$ Albrycht Radziwiłł (1558-1592) - the Grand Marshal of Lithuania from 1586 to 1592 .

${ }^{67}$ Hieronim Rozrażewski (1546-1600) - the bishop of Kujawy from 1582 to 1600. 
małżonki swej ${ }^{68}$. W którem tė̇ i sam był, mając kwarantannę. Potem die 23. Maii [maja] znowu przeciwko Arcyksiężnie Jej Mości potykając, wyjachał. Tegoż die [dnia] ksiądz biskup kujawski do Krakowa wjechał, zostawiwszy Arcyksiężnę w Freysztacie.

Dnia 24. Maii [maja] w niedzielę ksiądz biskup krakowski Radziwiłł ${ }^{69}$ posłem od Papieża ${ }^{70} z$ winszowaniem Jego Królewskiej Mości do Krakowa wjachał, którego wszyscy senatorowie natenczas w Krakowie będący, duchowieństwo Pan marszałek koronny ${ }^{71}$ ze wszytkiem niemal dworem potkali.

Dnia 26. Maii [maja] Król Jegomość wyjachawszy do Łobzowa $^{72}$ i tamże wszytkie poczty oglądawszy, ruszył się z nimi przeciwko Arcyksiężnie, które Pan Koniecpolski ${ }^{73}$, poszykowawszy poczty, po prawej ręce postawił, a piechotę i mieszczany po lewej ręce. A gdy się już Arcyksiężna przybliżała ku samym namiotom [sheet 2], Pan Bujanowski ${ }^{74}$ od Króla Jego Mości z karety, która na fl. 4000 szacowano, w której szło koni 8 gniadych, tureckich, które na druga fl. 4000 szacowano, do której Arcyksiężna wsiadać nie chciała i na swej aż do namiotów przyjachała i zsiadłszy, szła $z$ matka ${ }^{75}$ do namiotu swego, gdzie się rozburdawszy i ochędożywszy, wyszły obiedwie pod vellum [baldachim], gdzie też do nich Król Jego Mość z Królową starą ${ }^{76}$ i z Królewną szwedzką ${ }^{77}$ witał, od którego rzecz czynił ksiądz podkanclerzy koronny ${ }^{78}$, a od Arcyksiężny

${ }^{68}$ Maryna Myszczanka of Makowice (1563-1600) - daughter of the castellan of Wołyń, Michał Myszka.

69 Jerzy Radziwiłł (1556-1600) - the bishop of Cracow from 1591 to 1600.

${ }^{70}$ Clement VIII [Ippolito Aldobrandini] (1536-1603) - the Pope from 1592 to 1605.

${ }^{71}$ Andrzej Opaliński (1540-1593) - the Grand Marshal of the Crown from 1573 to 1593.

${ }^{72}$ There is a royal palace in Łobzow dating back to the $14^{\text {th }}$ century rebuilt in the mannerist style during the reign of Stephen Báthory.

${ }^{73}$ Aleksander Koniecpolski (died 1609) - envoy from the voivodship of Sieradz, the castellan of Sieradz from 1597, the starost of Żarnowiec, the voivode of Sieradz from 1606.

${ }^{74}$ This is probably about Jan Bojanowski (ca. 1549-1607) - at that time the starost of Bobrujsk and the gentleman of the bedchamber.

${ }^{75}$ Maria Anna of Bavaria (1551-1608) - the Archduchess of Austria.

${ }^{76}$ Anna Jagiellon (1523-1596) - daughter of Sigismund I the Old and Bona Sforza, married to Stephen Báthory, the Queen of Poland between 1575 and 1596.

${ }^{77}$ Anna Vasa of Sweden (1568-1625) - Swedish princess, daughter of John III of Sweden and Cathrine Jagiellon, sister of Sigismund III Vasa.

78 Jan Tarnowski (1550-1605) - the deputy chancellor of the Crown from 1591 to 1598 . 
odpowiadał biskup londeński ${ }^{79}$. Po przywitaniu rozeszli się każdy do swego namiotu, zaczem Pan Koniecpolski piechotę i poczty 2. rzędoma wprzód ruszył, za któremi Król Jego Mość ruszył się $z$ Arcyksiężna, która zaraz $z$ namiotu wsiadła $z$ matką do karety królewskiej i tak jachali przez Kleparz do miasta samego, w którem były 3 . arces triumphales [łuki triumfalne], na których różni mniszchowie i piszczykowie różnie grali, do zamku przyjachawszy, szli prosto do kościoła, gdzie Te Deum lauda mus [Ciebie Boga wysławiamy] śpiewano, nabożeństwa swe Panu Bogu oddawszy, prowadził [sheet 2v] Król Jmć Arcyksiężnę na pałacze do gmachów naznaczonych i tam mało postawszy, Król Jego Mość odszedł do swego pokoju. Potem wieczerzę dano.

Nazajutrz die [dnia] 27. Maii [maja] bywszy Król Jego Mość msze w kościele $z$ Arcyksiężna, $z$ matka, $z$ Królową stara, $z$ Królewną szwedzką. Z kościoła przyszedłszy, rozeszli się do swych pokojów. Potym szli do obiadu pod głowy ${ }^{80}$ i siedzili na majestacie Król w pośrzodku, po prawej ręce siedziała Królowa stara i Królewna, po lewej ręce siedziała Arcyskiężna, podle niej matka jej, a podle starej Arcyksiężny na rogu stołu siedział lancgraf ${ }^{81} z$ żoną swa ${ }^{82}$, nic więcej.

Dnia 28. Maii [maja] Król Jego Mość przyszedłszy z kościoła rano, zasiadł $\mathrm{w}$ radzie, gdzie biskup kujawski $z$ Panem marszałkiem poselstwo $z$ siebie zdali strony traktatów u Cesarza Jegomości ${ }^{83}$ o matrimonium [małżeństwo] z Arcyksiężną. Potem posłowie Cesarza Jego Mości ${ }^{84}$, ksiądz biskup wrocławski ${ }^{85}$ i lancgraf oddali Królowi Jego Mości Arcyksiężnę Annę, winszując Błogosławieństwa Pańskiego. [sheet 3]

Dnia 31. Maii [maja] rano ksiądz kardinał biskup krakowski, legat natenczas papieski, przyszedł do Króla Jego Mości, którego Król Jego Mość przez izbę wszedłszy, u wtórych drzwi potkał, gdzie

79 This is probably about Jerzy Stobacus, the bishop of Lavant.

80 The audience hall in Wawel.

${ }^{81}$ Georg IV Ludwig (1563-1613) - landgraf von Leuchtenberg from 1586 to 1613.

${ }^{82}$ Marie Salome von Baden (1563-1600) - wife of Landgraf Georg IV Ludwig from 1584 .

${ }^{83}$ Hieronim Rozrażewski and Albrycht Radziwiłł were envoys to the Emperor in 1592.

${ }^{84}$ Rudolf II Habsburg (1552-1612) - the Holy Roman Emperor from 1576 to 1612.

${ }^{85}$ Andreas Jerin (1540-1596) - the bishop of Wrocław from 1585 to 1596. 
trochę bywszy, ksiądz kardinał odszedł do kościoła. A zatym ubrano Króla Jego Mości jako do koronatii w kapę, w którym ubierze już w koronie sceptrum [berło] i jabłko mając w ręku, szedł do kościoła, przed którem wojewoda sędomirski ${ }^{86}$ niósł na półmisku koronę tę, która miała być koronowana Królowa. Sceptrum [berło] niósł wojewoda kaliski ${ }^{87}$, jabłko wojewoda łęczicki ${ }^{88}$. Za Królem Jego Mością drugiemi drzwiami Arcyksiężna weszła do kościoła, do swego majestatu. Stamtąd szli Król, za nim Arcyksiężna do ołtarza wielkiego, u którego kommunikowali. Tamże im ksiądz kardynał ślub dał. Potem szli na swe miejsca do majestatów, za tym msza, przy której triumphi [triumfy] się różne działy. $Z$ dział, $z$ rusznic strzelano [...] różne, Król Jego Mość na ofiarę chodził i Arcyksiężna Anna. Potem przed epistołą była koronowana od księdza biskupa kujawskiego, po której była od dwu [sheet 3v] biskupów na Majestat Królewski prowadzona, tamże pospołu nabożnie modlili aż do końca mszy.

Po mszy szli oboje do zamku: Król Jego Mość do swojego pokoju i rozebrał się $z$ dalmatyki, a Królowa do swojego ze wszytkiemi Paniami i tam była, aż dano jeść. Szedł wprzód Król do stołu, potem Panowie senatorowie Królowa Jej Mość przyprowadzili do stołu, tamże siedzieli w Majestacie, po prawej ręce siedział ksiądz kardynał jako posel, naprzeciwko niego przed stołem ksiądz biskup wrocławski, a na boku lancgraf, Król Jego Mość we śrzodku, Królowa młoda podle niego, po lewej stronie Arcyksiężna stara $z$ Królewną szwedzką. Podle lancgrafa żona jego niżej siedzieli, a $z$ obu stron sali stoły stały. Dawano na 24 misy, do kożdej po 16 półmisków. Po prawej ręce siedzieli posłowie obcy, senatorowie koronni i litewscy, inni też zacni cudzoziemcy, a po lewej ręce białegłowy cudzoziemki i nasze. Potem skoro po obiedzie szedł Król Jego Mość do swego pokoju, Królowa też do swego, a gdy wieczerza gotowa była, Król Jego Mość u Królowej Jej Mości jadł na jej pokoju, a do stołu pan[sheet 4] -ny jej służyły, nie był żaden urzędnik.

Dnia 1. Iunii [czerwca] Król Jego Mość skoro po obiedzie tańcy się zabawił pod głowami godzinę w noc, a potem u Królowej wieczerzał. Panny do stołu służyli.

Dnia 2. Iunii [czerwca] rano wstawszy, Król Jego Mość mszę w kościele był, Arcyksiężna $z$ Królowa młoda na pokoju mszy

\footnotetext{
86 Jerzy Mniszech (ca. 1548-1613) - the voivode of Sandomierz from 1589 to 1613.

${ }^{87}$ Piotr Potulicki (died 1606) - the voivode of Kalisz from 1584 to 1604.

${ }^{88}$ Stanisław Miński (ca. 1561-1607) - the voivode of Łęczyca from 1591 to 1607.
} 
słuchali. Potem Królowi Jego Mości z kościoła przyszedłszy, przed obiadem oddawano upominki na pokoju Królowej młodej.

\section{Naprzód}

Od Króla Jego Mości wojewoda brzeski ${ }^{89}$ Pan $_{\text {Graf }}^{90}$ i Panowie łożniczowie one nieśli. To jest:

$\operatorname{Kanak}^{91} \mathrm{z}$ wielkiemi dyjamenty $\mathrm{i}$ rubinami $\mathrm{u}$ niego pereł uryjańskich $^{92}$, które zowią 'Bezary' 30. K temu krzyżyk wszytek $z$ dyjamentami robotą barzo piękną i kosztowna, który Król Jego Mość kupił za fl. 18000.

Drugi kanak $z$ krzyżykiem podobny temuż, tylko $z$ kamienie mniejsze i proporcja mniejsza kupiony za fl. 9000. [sheet 4v]

Szkatułę kryształowa złotem i drogiemi kamieńmi oprawna, kosztuje 6000 fl., w niej łańcuch perłowy z pereł uryjańskich, każda perła po fl. 8 .

\section{Od Cesarza Jego Mości}

Ksiądz biskup wrocławski $z$ lancgrafem Kanak $z$ dyjamentami i krzyżyk szacowany na fl. 5000 .

Od Królowej Jej Mości starej

Oddawał Pan łęczicki ${ }^{93}$ łańcuch $\mathrm{z}$ pereł uryjańskich i kanak dyjamentowy, i dwa krzyżyki, jeden rubinowy, drugi diamentowy.

\section{Od Królewny szwedzkiej}

Kanak z krzyżykiem $z$ rubinów i diamentów z jednego przypięty.

\footnotetext{
${ }^{89}$ Andrzej Leszczyński (ca. 1559-1606) - the voivode of Brześć Kujawski from 1591 to 1606.

${ }^{90}$ Perhaps this refers to Gustaw Brahe (1558-1615) - the debt collector of Sigismund III Vasa from 1587, royal chamberlain from 1593.

${ }^{91}$ Necklace.

92 The name for oriental pearls. In the modern era those imported from East India were the most valuable.

${ }^{93}$ See footnote 74 .
} 
Od Księcia Palatina reńskiego ${ }^{94}$

Kanak $z$ rubinami i z dyjamentami szacowany na fl. 3000.

I od Księcia saskiego ${ }^{95}$

Kanak piękny z krzyżykiem $z$ rubinami niemałemi, a drugi kanak $z$ diamentami ostremi szacowano. [sheet 5]

Od Księcia Bawarskiego ${ }^{96}$

Kubeł wielki, piękną robotą ze sczere<g>o złota szacowano na 3000 koron.

Od Hanszpacha ${ }^{97}$

Kanak $z$ krzyżykiem dyjamentowym $z$ rubinami, $\mathrm{k}$ temu łańcuch $z$ zawieszeniem $z$ rubinami i dyjamentami szacowany na fl. 3000.

Od arcybiskupa gnieźnieńskiego ${ }^{98}$

Dwa prawie wielkie składane roztruchany ${ }^{99}$.

Od księdza biskupa kujawskiego

Dwa kubki wielkie.

${ }^{94}$ Frederick IV Wittelsbach of Palatinate-Simmern (1574-1610) - the Elector Palatine of the Rhine from 1574 to 1610 .

${ }^{95}$ Christian II Wettin (1583-1611) - the Elector of Saxony between 1591 and 1611. Due to his young age his mother, Sophie of Hohenzollern, together with Duke Frederick William I von Sachsen-Weimar assumed the regency from 1591 to 1601.

${ }^{96}$ William V the Pious Wittelsbach (1548-1626) - the Duke of Bavaria from 1579 to 1597.

${ }^{97}$ George Frederick Hohenzollern (1539-1603) - the Margrave of Ansbach and Bayreuth from 1543 to 1603.

${ }^{98}$ Stanisław Karnkowski (1520-1603) - the archbishop of Gniezno and primate of the Kingdom from 1581 to 1603.

${ }^{99} \mathrm{Big}$, silver cup of zoomorphic shape sometimes decorated with precious stones. It was used to make toasts and as a table decoration. 
Od księdza biskupa łuckiego ${ }^{100}$

Bardzo cudny kubeł wielki.

Od księdza biskupa chełmskiego ${ }^{101}$

Kubeł jeden niemały.

Od Pana wojewody łęczyckiego

Krzyżyk dyjamentowy piękny za fl. 1000.

Od Pana wojewody brzeskiego

Jeleń z koralowemi rogami. Pies u niego srebrny. [sheet 5v]

Od Pana wojewody kijowskiego

Rustruchanów 7., a ósmy kubek przykryty.

Od Pana wojewody połockiego ${ }^{102}$

Rostruchany 2.

Od Pana wojewody nowogrodzkiego ${ }^{103}$

Kubek przykryty barzo piękną robotą.

Od Pana wojnickiego ${ }^{104}$

Łańcuch $z$ smalcem i noszenie $z$ pelikanem.

${ }^{100}$ Bernard Maciejowski (1548-1608) - the bishop of Euck from 1587 to 1600 .

${ }^{101}$ Stanisław Gomolinski (died 1604) - the bishop of Chełm from 1591 to 1600.

102 Mikołaj Dorohostajski (ca. 1530-1597) - the voivode of Polotsk from 1574 to 1597.

${ }^{103}$ Teodor Skumin Tyszkiewicz (1533-1618) - the voivode of Nowogródek from 1590 to 1618.

104 Jan Tęczyński (died 1593) - the castellan of Wojnicz from 1571 to 1593. 
Od księdza podkanclerzego

Kubek wielki $z$ białem smalcem.

Od Jegomości Pana podkanclerzego litewskiego ${ }^{105}$

Rostruchan.

Od Jegomości Pana podskarbiego litewskiego ${ }^{106}$

Rostruchan cudną robota niemały.

Od krakowian

Ośm kubków cudnych i wielkich. [sheet 6]

Poznańczycy:

Miednica wielka i naliwka pozłocista.

Lwowianie:

Wielki prawie rostruchan, a w nim 1000 aug.

Gdańsczanie:

Łańcuch i noszenie $z$ dyjamentami. Miednica $z$ naliwką pozłocista. Kubek barzo wielki, szyroki i wysoki, w niem 500 portugalów. $\mathrm{K}$ temu 3. rostruchany niemałe.

Ryżanie:

Dwa prawie wielkie kubki i 100 portugalów.

Pod die [dnia] 2. Iunii [czerwca], godzina $\mathrm{w}$ noc race pusczano i różne ogniemi spectatula [widowiska] czyniono.

${ }^{105}$ Gabriel Woyna (died 1615) - the deputy chancellor of Lithuania from 1589 to 1615 .

106 Dymitr Chalecki (ca. 1550-1598) - the grand treasurer of Lithuania from 1590 to 1598. 
Dnia 3. Iunii [czerwca] tak się też dzień z tańcami skończył.

Dnia 4. Iunii [czerwca]. Skoro po obiedzie tańce były aż ku wieczorowi, zapalono świece, potem w sali, w której wyszła wieża i w pośrzód sali stanęła, z której najpierwej wyszło 62. alabardników w maszkarach, ci 2. rzędoma stanęli. [sheet 6v]

Za niemi wyszło 8. śpiewaków, którzy tańcując, śpiewali \{po\} polsku, za nimi wyszło 16. muzyków, którzy też grając z nimi, długo tańcowali.

Potem wyszło 6. po męsku ubranych. Potem 6. panien, którzy $z$ niemi długo różne tańce tańcowali, trwając aż do 6 . godziny w noc. Potem ta wieża odeszła, zatym się Królowa $z$ sale do swego pokoju ruszyła.

Dnia 6. Iunii [czerwca] od KrólJego Mość biskupowi wrocławskiemu i lancgrafowi tak też i innym Panom $z$ obcych krajów upominki dawano.

Tegoż dnia godzinę w noc była Królowa młoda $z$ matką do sale prowadzona. Tamże różne inwentie były prowadzone i pokazowane:

1. Jego Królewskiej Mości wyszedł wóz, na którem 4. virtutos cardinales $^{107}$ [cnoty kardynalne] i lew żywy.

2. Pana starosty krzepickiego ${ }^{108}$, skala, w której śpiewacy. [sheet 7]

\{3.\} Pana Zygmunta Myszkowskiego ${ }^{109}$ żółw, na której młodzieniec w maszkarze i wieńcu siedział.

\{4.\} Pana Stanisława Stadnickiego ${ }^{110}$ fonntana Dyany $z$ nimfami jej.

5. Panów Krasickich młodych ${ }^{111}$ murzynka wielka, przed którą szła muzyka.

6. Pan podczaszego litewskiego ${ }^{112}$ koncza, którą ciagnęli 2. delfinowie, a na niej Neptunus [Neptun] siedział, przed którym na 4. sztorciech grano.

${ }^{107}$ Prudence, temperance, fortitude and justice.

${ }^{108}$ Mikołaj z Podhajec Wolski (1553-1630) - the starost of Krzepice from 1566 to 1630 .

${ }^{109}$ Zygmunt Gonzaga Myszkowski (ca. 1562-1615) - creator of the so-called Myszkowski ordinance, later great marshal of the Crown from 1600 to 1615 .

${ }^{110}$ Stanisław Stadnicki 'the Devil of Łańcut' (ca. 1551-1610) - the Starost of Zygwold (Sigulda) from 1593 to 1610.

${ }^{111}$ Marcin Krasicki (1574-1631) - later the castellan of Lwów from 1616 to 1630, in 1592 he was a royal courtier; and Jerzy Krasicki (died 1645) - later the starost of Dolina from 1605 to 1641 and the ensign of Halicz from 1610 to 1638.

${ }^{112}$ Krzysztof Monwid Dorohostajski (died 1579) - the cupbearer of Lithuania from 1592 to 1596. 
7. Pana starosty chęcińskiego ${ }^{113}$ morze, na którem 2 . syreny były i pani piękna Wysłą nazwana i innych niemało było różnych inwentii.

Potem się turniej zaczął, sam Król zaczął, z innych Wiela kruszył pikami, a potem mieczami, co wszytko trwało aż do 5. godziny w noc.

Dnia 7. Iunii [czerwca] w niedzielę w rynku były różne inwentie około szranków, które były postawione dla gonitw.

\section{Inwentie [sheet $7 \mathrm{v}$ ]}

1. Szedł wóz Jego Królewskiej Mości, na którem Hercules $z$ Atlantem ${ }^{114}$ niebo nieśli.

2. Pana Zygmunta Myszkowskiego okręt, który ciagnęli 3. krokodyle, na którym były działa.

3. Pana podczaszego litewskiego wóz triumfalny, na którem sam w pośrzodku siedział jako Perseus ${ }^{115}$, dzierżąc w ręku na mieczu głowę medusy. Za nim siedział Mars i Pallas, a przed nim 3. Gratiæe [Gracje] ${ }^{116}$ śpiewające. Ten wóz ciagnęli 4. jednorożce, $z$ których każdego $z$ osobna nimfy wiodły. Za tem wozem 2. Gorgones Pegasum, to jest konia skrzydlatego wiodły, na którego on potym wsiadł i gonił.

4. Pana starosty chęcińskiego wóz, na którym sam $z$ niemi siedział w koronie, jako Minos sceptrum [berło] w ręku mając, ten wóz pełen był rac, który ciagnęli smoków 3., mając ogień pałajacy $z$ pasczęk.

5. Tegoż Pana chęcińskiego zatem wozem szła skala, która od rac sama zgorzała, $z$ której koń wyskoczył.

6. Pana krajczego koronnego ${ }^{117}$ była hydra o 7 . głowach, $z$ ogona się jej paliło. [sheet 8]

${ }^{113}$ Piotr Gonzaga Myszkowski (ca. 1560-1601) - the starost of Checiny from $1587 / 1588$ to 1601 .

${ }^{114}$ In architecture the figure of a muscular man supporting different architectural elements such as a balcony or terrace with his body. Atlantes may also serve as support in the place of a pillar or column.

${ }^{115}$ Perseus - hero in Greek mythology, the son of Zeus and Danaë, husband of Andromeda.

116 The three Graces - in Greek mythology they were goddesses of beauty, mirth and elegance. They were considered guardians of art. They were presented as women holding hands.

${ }^{117}$ Piotr Opaliński (1566-1600) - the crown carver from 1588 to 1600. 
7. Pana Stanisława Stadnickiego był sam ubrany jako gospodarz, na parepiezwackiem siedzac, za nim jachał urzędnik $z$ Barbarii, Regestrum [rejestr] mając w ręku, przed nim pług szedł ze 2. wołami, za pługiem siano i to wszytko czyniono, co gospodarstwu należy.

8. Pana starosty krzepickiego sam na plac konno przyjachał w dziwnych ubiorach, bo inwentii nie zgotowano.

9. Pana Bekieszowa ${ }^{118}$ miał łodzią, na której sam siedział, mając pełno w niej strzelby i potem obyczajem morskich zbójców uderzył na okręt Pana Myszkowskiego, tamże na się wszytkę strzelbę wypuścili i ten okręt tę łodzia pojmał.

10. Pana starosty śniatyńskiego ${ }^{119} \mathrm{z}$ Panem Sieniawskim ${ }^{120}$ przyjachał sam jako poseł perski, za któremi szli 2. wielbłądy, na których siedziało dwoje chłopiąt, mając w ręku po kubku złocistem wielkim jako dary jakie. [sheet 8v]

11. Pana Łaskiego ${ }^{121}$ szła galera, na której więźniowie przykuwani, wiosłami robiac, za nia na koniach po murzyńsku jachali. Pan Łaski, starościć warszawski Pan Plaza ${ }^{122}$, Pan Woyna ${ }^{123}$, pisarz etc.

A po tych wszytkich inwentiach zaczęły się gonitwy i trwały do samego zmirzchu.

Dnia 8. Iunii [czerwca] Król Jego Mość $z$ Królową młodą i Arcyksiężna starą wyjachał do Niepołomic. Tegoż dnia biskup wrocławski, lancgraf i inni posłowie cudzoziemscy odjachali.

Dnia 9. Iunii [czerwca] przyjachał poseł od Panów Weneckich ${ }^{124}$, który przez dalekość drogi wesela omieszkał. Wielkie i kosztowne podarki Królowi Jego Mości przywiózł, które na fl. 12000 szacowano.

Dnia 10. Iunii [czerwca] posłów z Jędrzejowa ${ }^{125}$ Król Jego Mość słuchał, które poselstwo od nich niewdzięcznie przyją, [sheet 9] iż takich seditii pod bokiem Jego Królewskiej Mości rozburzać się ważyli. Na które poselstwo respons do sejmu odłożył, odprawiono ich 15. Iunii [czerwca].

118 Bekiesz - a royal courtier.

${ }^{119}$ Mikołaj Jazłowiecki (1550-1595) - the starost of Śniatyń from 1575 to 1595.

120 This may refer to Prokop Sieniawski (died 1596) - later the court marshal of the Crown from 1594 to 1596.

${ }^{121}$ Olbracht Łaski (1536-1605) - the voivode of Sieradz from 1566.

122 This may refer to Jan Płaza, the starost of Lubaczów.

${ }^{123}$ Maciej Woyna - Lithuanian writer in 1589, the secretary of Sigismund III Vasa.

${ }^{124}$ This probably refers to Pietro Duodo (1554-1610), a Venetian envoy to the Commonwealth in 1592.

${ }^{125}$ In 1592, there was a meeting of noblemen in Jędrzejów with participation of the Chancellor and Grand Hetman of the Crown Jan Zamoyski. 
Eodem [tego samego] die [dnia] 15. Król Jego Mość z Królowa młoda, Arcyksiężnę Jej Mość starą z Krakowa na noc do Balic ${ }^{126}$ prowadził. 16. w Kurowie ${ }^{127}$ nocował. Tamże się żegnali nazajutrz 17. Arcyksiężna Jej Mość z córką swą Królową Jej Mością żałosne żegnanie czyniąc w społecznem płaczu smutno się rozstały i rozjachały.

Eodem [tego samego] 18. Iunii [czerwca] do Krakowa Król Jego Mość z Królową Jej Mością młodą wrócił się.

\section{Bibliography}

\section{Archival sources}

Biblioteka Kórnicka PAN [BK PAN]

(The Kórnik Library of the PAS)

MS 245, 309.

Biblioteka Ksiażąt Czartoryskich [BCz]

(The Princes Czartoryski Library in Cracow)

MS 351.

\section{OLD PRINTS}

Biblioteka Jagiellońska w Krakowie

(The Jagiellonian Library in Cracow)

MS CIM QU. 5320.

Biblioteka Książąt Czartoryskich w Krakowie [BCz]

(The Princes Czartoryski Library in Cracow)

197 II, 212 I, 405 I, 456 I, 1977 II.

\section{Printed SOURCes}

Grabowski A., Ojczyste spominki w pismach do dziejów dawnéj Polski, diaryusze, relacye, pamiętniki i.t.p. służyć mogące do objaśnienia dziejów krajowych tudzież listy historyczne do panowania królów Jana Kazimiérza i Michała Korybuta oraz listy Jana Sobieskiego marszałka i hetmana wielkiego koronnego, Kraków 1845, vol. I, pp. 36-39.

Heidenstein R., Dzieje Polski od śmierci Zygmunta Augusta do roku 1594: ksiag XII, transl. M. Gliszczyński, elaborated and ed. J. Byliński, W. Kaczorowski, Opole 2015.

${ }^{126}$ Probably the royal family spent the night in the palace of the Firlej family in Balice.

${ }^{127}$ Kurów - former village, presently a district of Bochnia. 
Ioachimi Bilscii Carmina Latina. Nunc primum in unum volume collecta, ed. T. Bieńkowski, Warszawa 1962.

Kronika mieszczanina krakowskiego z lat 1575-1595, ed. H. Barycz, Kraków 1930.

Piasecki P., Kronika Pawła Piaseckiego biskupa przemyślskiego, Kraków 1870.

Radziwiłł A.S., Pamiętnik o dziejach w Polsce, vol. I (1632-1636), elaborated and tranls. A. Przyboś, R. Żelewski, Warszawa 1980.

The house of Vasa and the house of Austria: correspondence from the years 1587 to 1668. Pt. 1, The times of Sigismund III, 1587-1632. Vol. 1, ed. R. Skowron, Katowice 2016.

Zawadzki K., Gazety ulotne polskie i Polski dotyczace XVI-XVIII wieku. Bibliografia. Vol. 1, 1514-1661, Wrocław 1977.

\section{Studies}

Barwicka-Makula A., Anna Austriaczka (16 sierpnia 1573-10 lutego 1598), [in:] Poczet władczyń Polski, ed. B. Czwojdrak, Kraków 2017, pp. 297-301.

Barwicka-Makula A., Od wrogości do przyjaźni. Habsburgowie austriaccy wobec Polski w latach 1587-1592, doctoral dissertation under the scientific supervision of Associate Professor R. Skowron PhD, Katowice 2013.

Barwicka-Makula A., Stół królewski podczas uroczystości weselnych Zygmunta III Wazy i Anny Austriaczki w 1592 roku, [in:] Historia naturalna jedzenia: między antykiem a XIX wiekiem. Materiały z międzynarodowej konferencji naukowej zorganizowanej przez Muzeum Historyczne Miasta Gdańska i Uniwersytet Gdański dla upamiętnienia 100-lecia otwarcia Muzeum Wnętrz Mieszczańskich w Domu Uphagena $w$ dniach 3-4 listopada 2011 roku, ed. B. Możejko, Gdańsk 2012, pp. 173-179.

Bochnak A., Portrety Zygmunta III i Anny Austriaczki w Muzeum Sztuki UJ, 'Prace Komisji Historii Sztuki Polskiej Akademii Umiejętności’ [Kraków] 1946, vol. VIII, pp. 327-335.

ChrościckiJ.A., Barokowaarchitekturaokazjonalna, [in:] WiekXVII. Kontrreformacja. Barok, ed. J. Pelc, Wrocław 1970, pp. 229-254.

Dubas-Urwanowicz E., Wesele Jana Zamoyskiego z Gryzelda Batorówną, 'Białostockie Teki Historyczne' 2011, vol. IX, pp. 237-251.

Estreicher K., Bibliografia polska, vol. XII, Kraków 1891.

Falniowska-Gradowska A., Leitsch W., Gonitwa $w$ maszkarach na Rynku Krakowskim (7 czerwca 1592 r.), 'Rocznik Krakowski' 1985, vol. LI, pp. 31-56.

Filipczak-Kocur A., Wesele Zygmunta III i Anny w 1592 r. oraz koronacja królowej $w$ relacjach niemieckojęzycznych i polskich gazet ulotnych, [in:] Wesela, chrzciny i pogrzeby w XVI-XVIII wieku. Kultura życia i śmierci, ed. H. Suchojad, Warszawa 2001, pp. 91-104.

Grzebień L., Sokołowski (Socolovius) Stanisław h. Gozdawa (1537-1593), [in:] Polski słownik biograficzny, vol. XL, Warszawa-Kraków 2000-2001, pp. 183-189. 
Kadzik D., Utrzymanie królewskiej teściowej: wizyta Marii Bawarskiej podczas wesela Zygmunta III Wazy z Anna Habsburg (23 maja - 16 czerwca 1592 r.), Kraków 2017.

Keller K., Erzherzogin Maria von Innerösterreich (1551-1608). Zwischen Habsburg und Wittelsbach, Wien-Köln-Weimar 2012.

Kutrzeba S., Koronacje królów i królowych w Polsce, Warszawa 1918.

Kutrzeba S., Ordo coronandi Regis Poloniae, 'Archiwum Komisji Historycznej' [Kraków] 1909-1913, vol. XI, pp. 133-216.

Leitsch W., Das Leben am Hof König Sigismunds III. von Polen, Bd. II, Kraków 2009.

Lepszy K., Anna Austriaczka, [in:] Polski słownik biograficzny, vol. I, Kraków 1935, pp. 132-133.

Lepszy K., Rzeczpospolita Polska w dobie Sejmu Inkwizycyjnego (1589-1592), Kraków 1939.

Leszczyńska A., O muzyce $w$ obrzędach koronacyjnych królów polskich, 'Polski Rocznik Muzykologiczny' 2015, vol. XIII, pp. 81-98.

Malicki M., Joachima Bielskiego nieznane polskie 'Epithalamion' na ślub Zygmunta III $i$ Anny Austriaczki, 'Biuletyn Biblioteki Jagiellońskiej' [Kraków] 1994, vol. XLIV, No. 1-2, pp. 119-129.

Nowak-Dłużewski J., Okolicznościowa poezja polityczna w Polsce. Zygmunt III, Warszawa 1971.

Pirożyński J., Krakowskie uroczystości państwowe i dworskie w drugiej połowie XVI wieku $w$ świetle ówczesnych prototypów prasowych, [in:] Theatrum ceremoniale na dworze ksiąząt i królów polskich, eds M. Markiewicz, R. Skowron, Kraków 1999, pp. 193-205.

Podhorodecki L., Wazowie w Polsce, Warszawa 1985.

Polscy dyplomaci w Wiedniu 1515-2015, ed. B. Dybaś, Wiedeń 2015.

Rokosz M., 'Forum Polonorum et Via Regia'. Rynek krakowski i Droga Królewska scena wydarzen państwowych, religijnych, narodowych i społecznych 12572010, [in:] Rynek krakowski odkryty na nowo, ed. E. Firlet, Kraków 2014, pp. 405-610.

Rożek M., Polskie koronacje i korony, Kraków 1987.

Rożek M., Uroczystości w barokowym Krakowie, Kraków 1976.

Rudzki E., Polskie królowe. Żony królów elekcyjnych II, Warszawa 1987.

Ruszczyc J., Portrety Zygmunta III i jego rodziny, 'Rocznik Muzeum Narodowego w Warszawie' [Warszawa] 1969, vol. XIII, part 1, pp. 151-264.

Siarczyński F., Obraz wieku panowania Zygmunta III króla polskiego i szwedzkiego czyli obraz stanu, narodu i kraju..., Poznań 1843.

Suchojad J., Wesela, chrzciny i pogrzeby w XVI-XVIII wieku. Kultura życia i śmierci, Warszawa 2001.

Szweykowska A., Widowiska baletowe na dworze Zygmunta III (4 czerwca 1592, 13 oraz 18 grudnia 1605), 'Muzyka' 1966, vol. XI, No. 1 (40), pp. 27-36. 
Targosz K., Królewskie uroczystości weselne w Krakowie i na Wawelu w 15121605, Kraków 2007.

Targosz K., Oprawa artystyczno-ideowa wjazdów weselnych trzech sióstr Habsburżanek (Kraków 1592 i 1605, Florencja 1608), [in:] Theatrum ceremoniale na dworze ksiąząt i królów polskich, eds M. Markiewicz, R. Skowron, Kraków 1999, pp. 207-244.

Vocelka K., Habsburgische Hochzeiten 1550-1600. Kulturgeschichtliche Studien zum manieristischen Repräsentationsfest, Wien 1976.

Windakiewicz S., Dzieje Wawelu, Kraków 1925.

Wisner H., Dyplomacja polska w latach 1572-1648, [in:] Historia dyplomacji polskiej, vol. II (1572-1795), ed. Z. Wójcik, Warszawa 1982, pp. 5-161.

Wisner H., Zygmunt III Waza, Wrocław 1991.

Zawadzki K., Poczatki prasy polskiej. Gazety ulotne i seryjne XVI-XVIII wieku, Warszawa 2002. 